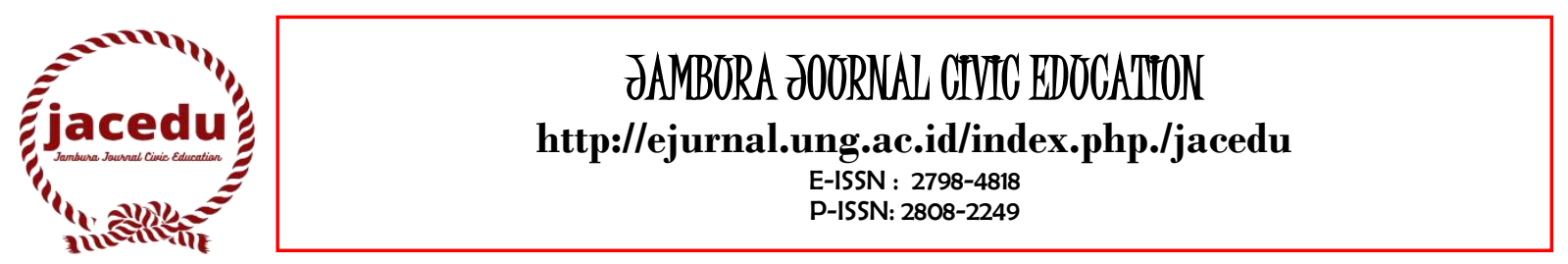

\title{
PERAN PEMERINTAH DESA DALAM MEMBERDAYAKAN MASYARAKAT MELALUI \\ DANA DESA (DI DESA BUBE, KECAMATAN SUWAWA, KABUPATEN BONE BOLANGO, PROVINSI GORONTALO)
}

\section{Lucyane Djafar ${ }^{1}$, Roni Lukum ${ }^{2}$, Sukarman Kamuli, ${ }^{3}$ Asmun Wantu ${ }^{4}$ Fakultas Ilmu Sosial, Universitas Negeri Gorontalo}

\author{
lucyanedjafar@gmail.com \\ ronilukum@gmail.com \\ sukarmankamuli@gmail.com \\ asmunwantu@gmail.com
}

\begin{abstract}
Info Artikel Abstrak
Sejarah Artikel:

Diterima (Desember) (2021)

Disetujui (Desember) (2021)

Dipublikasikan (Desember)

(2021)

\section{Keywords:}

Pemerintahan desa, pemberdayaan masyarakat, dana desa

Penelitian ini bertujuan untuk mengetahui bagaimana peran pemerintah desa dalam meningkatkan pemberdayaan masyarakat Desa Bube, apa saja faktor penyebab kurangnya pemberdayaan masyarakat desa Bube serta bagaimana upaya pemerintah desa untuk meningkatkan pemberdayaan masyarakat desa Bube. Penelitian ini menggunakan metode kualitatif, Melalui pendekatan ini, peneliti mendeskripsikan data temuan penelitian dari informasi sesuai dengan kenyataan yang ada di lapangan. Prosedur pengumpulan data yaitu dengan melakukan observasi, wawancara dan dokumentasi. Hasil penelitian ini menunjukan bagaimana peran pemerintah desa dalam meningkatkan pemberdayaan masyarakat desa, pemerintah desa Bube telah melakukan perannya dengan cukup baik terutama peran pemerintah desa sebagai fasilitator, motivator dan inovator sudah cukup baik terutama pada pelaksanaan program pemberdayaan masyarakat. Adapun Faktor penyebab kurangnya pemberdayaan masyarakat desa, yaitu dapat dilihat dari kondisi penduduk dan partisipasi masyarakat yang menyebabkan kurangnya pemberdayaan masyarakat di Desa Bube serta Upaya-upaya yang dilakukan pemerintah desa dalam meningkatkan pemberdayaan masyarakat desa, yaitu dengan memberikan akses, partisipasi, kontrol juga manfaat yang baik kepada masyarakat desa Bube.
\end{abstract}

\section{PENDAHULUAN}

Pemerintah desa merupakan lembaga perpanjangan pemerintah pusat memiliki peran yang strategis dalam peraturan masyarakat desa/kelurahan dan keberhasilan pembagunan

\footnotetext{
${ }^{1}$ Dosen PPKN UNG

${ }^{2}$ Dosen PPKN UNG

${ }^{3}$ Dosen PPKN UNG

${ }^{4}$ Dosen PPKN UNG
} 
nasional. Pemerintah desa terdiri dari kepala desa dan perangkat desa, yakni terdiri atas sekertaris desa, bendahara dan perangkat lainnya. Sesuai dengan rumusan pasal 1 angka 3 UU Desa kedudukan perangkat desa adalah "Pembantu" bagi kepala desa dalam menjalankan fungsi pemerintahan. Maka dari itu pemerintah desa memiliki tugas dan tanggung jawab masing-masing yang bertujuan untuk memajukan kemandirian dan kesejatraan desa.

Dalam mewujudkan tujuan desa yang mandiri dapat dimulai dari bagaimana menjalankan pemberdayaan masyarakat desa. Seperti yang diketahui pemberdayaan masyarakat adalah pendekatan pembangunan alternatif atau pembangunan sosial yang bertujuan menyelenggarakan pembangunan yang lebih berkeadilan. Pada pemberdayaan masyarkat desa menurut Undang-Undang No 6 Tahun 2014 dan Peraturan Pemerintah lebih berfokus pada bagaimana Pengelolaan dana desa tersebut sehingganya haruslah ada keseimbangan pengelolaan antara pemerintah desa dan masyarakat demi tercapainya pemberdayaan masyarakat yang adil.

Dalam pemberdayaan masyarakat peran pemerintah disini sangat dibutuhkan dalam menghidupkan desa yang masyarakatnya telah di berdayakan, adapun peran pemerintah desa dalam pemberdayaan lebih kepada memfasilitasi masyarakat lokal untuk merencanakan, memutuskan dan mengelola sumberdaya yang dimiliki sehingga pada akhirnya mereka memiliki kemampuan dan kemandirian secara ekonomi, ekologi dan sosial yang berkelanjutan. Jadi dapat di ketahui bahwa harapan besar pemerintah dalam pemberdayaan masyarakat yaitu ketika masyarakatnya telah mampu untuk mandiri dalam segi ekonomi, ekologi maupun sosial.

Pada permasalahan yang terjadi di Desa Bube, Kecamatan Suwawa, Kabupaten Bone Bolango Provinsi Gorontalo sesuai yang dijelaskan diatas peran pemerintah desa dalam memberdayakan masyarakat desa belum tercapai sesuai dengan yang diharapkan karena pada kegiatan pemberdayaan masyarakat ini misalnya seperti pengelolaan dana desa yang bisa dikatakan sudah baik tetapi masih ada hal yang perlu yang diperhatikan mengenai jalanya program-program pemberdayaan masyarakat. Pada data yang didapatkan di desa Bube dapat diketahui program-program pemberdayaan yang di jalankan dari tahun-ketahun yaitu ada beberapa antara lain : ada program menjahit, program ternak sapi, program peningkatan kapasitas aparat dan masyarakat serta UMKM. Pada program pelatihan menjahit itu dilaksanakan sekitar tahun 2017 dan 2019, Program ternak sapi dilakukan sekitar tahun 2017, 2018 dan 2019, sedangkan program UMKM itu dilaksanakan pada tahun 2020. Dalam menjalankan program-program pemberdayaan ini agar bisa terlaksana dapat diketahui bahwa 
dana yang dilakukkan untuk setiap bidang berbeda-beda, seperti pada bidang pelatihan menjahit dana yang digunakan sekitar (Rp. 100.000.000), bidang ternak sapi 20 ekor sekitar (Rp.150.000.000), bidang UMKM itu seperti pemberian bantuan kepada masyarakat pedengan kecil sdengan dana sekitar (Rp. 2.500.0000) untuk setiap orang sedangkan untuk peningkatan kapasitas aparat dan masyarakat dengan dana sekitar (Rp.5.000.000).

Namun dalam menjalakan program-progaram pemberdayaan ini menemui beberapa kendala salah satu kendalan yang dialami aparat desa adaalah kurangnya partisipasi masyarakat dalam membantu dan mensuseskan program pemberdayaan yang ada di desa bube. Masyarakat desa lebih cenderung aktif jika mendapatan bantun dari program pemberdayaan setelah mendapat bantuan pada program pemberdayaan ini masyarakat kembali acuh bahkan terkadang tidak lagi berpatisipasi dalam mensussekan kegiatan dari program pemberdayaan masyarakat ini, tentunya ini menjadi suatu perhatian khusus dari pemerintah desa bube agar bagaimana cara pementah dapat merangkul dsetiap masyarakat agar bdapat berpartisipasi secara aktif dalam kegiatan pemberdayaan ini . Karena seperti yang diketahui bahwa suskses dan berjalannya pemberdayaan masyarakat ini dengan adanya kerjasama dan partisipasi yang baik dari pemerintah desa dan masyarakat jika pemeerintah desa atau masyarakat tidak berkerjasama dan tidak berpartisipasi dengan aktif maka yang menjadi tujuan pemberdayaan masyrakat ini tidak dapat tercapai sehingganya menyebabkan pemberdayaan masyarakat akan sulit tercapai. Dari permasalahan yang telah dijelaskan saya sebagai penulis dapat menangkat judul dari permasalahan ini adalah "peran pemerintah desa dalam memberdayakan masyarakat melalui dana desa (Di Desa Bube Kecamatan Suwawa Kabupaten Bone Bolango Provinsi Gorontalo)".

\section{METODE PENELITIAN}

Metode penelitian yang digunakan daam penelitian ini adalah metode kualitatif. Metode kualitatif adalah penenlitian dengan hasil data yang dikumpulkan bukanlah data yang dapat diuji dengan statistic. Melalui pendekatan ini, peneliti mendeskripsikan data temuan penelitian dari informasi sesuai dengan kenyataan yang ada di lapangan. Untuk mendapatkan data penelitian, yang menjadi instrument dalam penelitian ini adalah peneliti sendiri. 


\section{HASIL PENELITIAN DAN PEMBAHASAN}

\section{Peran Pemerintah Desa Dalam Meningkatkan Pemberdayaan Masyarakat.}

Dalam peran pemerintah desa dalam memberdayakan masyarakat melalui peran pemerintah desa sebagai fasilitator, motivator serta inovator ini jika dilihat sudah cukup baik, seperti dalam memfasilitasi pemberdayaan masyarakat pemerintah desa sudah menyediakan lokasi, alat dan bahan yang diperlukan dalam program pemberdayaan masyarakat. Dalam hal memotivasi masyarakat desa dalam meningkatkan partisipasi masyarakat dalam pemberdayaan masyarakat ini yang masih kurang hal tersebut dapat diketahui dari kurangnya partisipasi aktif masyarakat dalam setiap program pemberdayaan dan juga dapat dilihat dari partisipasi masyarakat yang hanya di awal kegiatan rogram pemberdayaan masyarakat serta dalam hal menginovasikan program pemberdayaan masyarakat sudah cukup baik dimana pemerintah desa menjalankan program pemberdayaan masyarakat seperti program pelatihan menjahit yang jika dilhat dengan peluangnya didunia usaha juga menguntungkan tetapi partisipasi masyarakat yang kurang sehingga masyarakat tidak terlalu mengikuti dengan baik program pelatihan menjahit, yang kedua menjalankan program ternak sapi serta program UMKM untuk masyarakat dalam usaha warung-warung kecil.

Tetapi seperti yang diketahui jika dilihat dari jumlah masyarakat miskin di Desa Bube sekitar 17\% yang jika lihat dari jumlah penduduk sekitar 113 orang, untuk masyarakat prasejaterah sekitar 22 orang, untuk keluarga sejatera 1 sekitar 91 orang, untuk keluarga sejaterah 2 sekitar 51 orang sejaterah sekitar 29 orang, jadi dari data yang ditemukan dapat diketahui bahwa jumlah penduduk miskin jauh lebih besar dari yang lainnya jika dihubungkan dengan peran pemerintah desa dalam memberdayakan masyarakat dapat diketahui bahwa peran pemerintah desa dalam memberdayakan masyarakat ini masih belum terlalu optimal hal tersebut dapat terlihat dari partisipasi masyarakat yang masih kurang serta jumlah penduduk miskin yang lebih dari 100 orang dapat diketahui bahwa peran pemerintah desa dalam memberdayakan masyarakat belum optimal karena masyarakat dengan adanya program-program pemberdayaan masyarakat ini masyarakat desa belum berdaya hal tersebut terlihat dari pastisipasi masyarakat dalam program pemberdayaan masyarakat yang masih kurang serta jumlah masyarakat miskin yang mencapai $17 \%$ sehingga diperlukan lagi 
peran pemerintah desa yang lebih optimal demi mencapai pemberayaan masyarakat yang lebih baik.

\section{Faktor Penyebab Kurangnya Pemberdayaan Pada Masyarakat.}

Faktor utama dari kurangnya pemberdayaan masyarakat yang ada di desa Bube ini adalah partisipasi masyarakat terhadap pentingnya berperan aktif dalam setiap program pemberdayaan masyarakat. Dan juga salah satu hal yang perlu diperhatiakan yaitu pemahaman masyarakat terhadap segala bentuk program pemberdayaan masyarakat, sehingganya jika masyarakat desa belum berpartisipasi dengan aktif maka peran pemerintah desa dalam memberdayakan masyarakat belum terlulu optimal karena masyarakt belum berdaya, sehingganya jika masyarakat masyarakat memahami lebih dalam apa itu pemberdayaan masyarakat akan lebih meningkatkan partisipasi masyarakat. Hal ini tentulah menjadi patokan utama yang perlu diperhatikan oleh pemerintah agara masyarakat lebih memahami lagi gunanya pemberdayaan masyarakat sehingga pemberdayaan masyarakat yang ada di desa Bube dapat berjalan dengan baik.

\section{Upaya Pemerintah Dalam Meningkatkan Pemberdayaan Masyarakat}

Berdasarkan hasil penelitian, Pemerintah desa sudah mengupayakan agar pemberdayaan masyarakat dapat berjalan dengan baik yaitu diataranya dengan memberikan akses yang baik untuk masyarakat, control atau pengawasan pada setiap program pemberdayaan yang ada didesa serta berupaya memberikan mamfaat untuk masyarakat dalam program pemberdayaan masyarakat, serta dapat meningkatkan partisipasi setiap pemerintah desa dan masyarakat desa, tetapi yang menjadi permasalahan adalah partisipasi masyarakat yang mash kurang sehingganya dengan upaya pemerintah desa dalam meningkatkan partisiapasi masyarakat ini bisa terlaksana dengan baik.

\section{KESIMPULAN}

Berdasarkan hasil penelitian yang telah dilakukan oleh penulis mengenai “Peran Pemerintah Desa Dalam Memberdayakan Masyarakat Melalui Dana Desa (Di Desa Bube Kecamatan Suwawa Kabupaten Bone Bolango Provinsi Gorontalo)". Maka kesimpulan dari hasil penelitian tersebut dapat diuraikan sebagai berikut: 
Peran pemerintah desa dalam memberdayakan masyarakat desa Bube belu terlalu optimal optimal hal tersebut dapat terlihat dari partisipasi masyarakat yang masih kurang serta jumlah penduduk miskin yang lebih dari 100 orang dapat diketahui bahwa peran pemerintah desa dalam memberdayakan masyarakat belum optimal karena masyarakat dengan adanya program-program pemberdayaan masyarakat ini masyarakat desa belum berdaya hal tersebut terlihat dari pastisipasi masyarakat dalam program pemberdayaan masyarakat yang masih kurang serta jumlah masyarakat miskin yang mencapai 17\% sehingga diperlukan lagi peran pemerintah desa yang lebih optimal demi mencapai pemberayaan masyarakat yang lebih baik. Tetapi jika dilihat dari memfasilitasi dan menginovasikan program pemberdayaan masyarakat sudah cukup baik tetapi dalam hal partisipasi masyrakat masih kurang.

Faktor utama dari kurangnya pemberdayaan masyarakat yang ada di desa Bube ini adalah partisipasi masyarakat terhadap pentingnya berperan aktif dalam setiap program pemberdayaan masyarakat. Dan juga salah satu hal yang perlu diperhatiakan yaitu pemahaman masyarakat terhadap segala bentuk program pemberdayaan masyarakat, sehingganya jika masyarakat masyarakat memahami lebih dalam apa itu pemberdayaan masyarakat akan lebih meningkatkan partisipasi masyarakat. Dalam mengupayakan pemberdayaan masyarakat, pemerintah desa sudah mengupayakan agar pemberdayaan masyarakat dapat berjalan dengan baik yaitu diataranya dengan memberikan akses yang baik, control atau pengawasan pada setiap program pemberdayaan yang ada didesa serta berupaya memberikan mamfaat untuk masyarakat dalam program pemberdayaan masyarakat, tetapi yang menjadi permasalahan adalah partisipasi masyarakat yang mash kurang sehingganya peran pemerintah desa dalam memberdayakan masyarakat masih belum optimal dikarenakan partisipasi masyarakat yang masih kurang dengan upaya pemerintah desa dalam meningkatkan partisiapasi masyarakat ini bisa terlaksana dengan baik. Peran pemerintah desa dalam memberdayakan masyarakat desa Bube sudah cukup baik terutama pada peran pemerintah sebagai fasilitator dan inovator hanya saja dalam peran pemerintah sebagai motivator karena partisipasi masyarakat masih dirasa kurang dan perlu untuk ditingkatkan baik dari pemerinta desa dan masyarakat desa.

Faktor utama dari kurangnya pemberdayaan masyarakat yang ada di desa Bube ini adalah partisipasi masyarakat terhadap pentingnya berperan aktif dalam setiap 
program pemberdayaan masyarakat. Dan juga salah satu hal yang perlu diperhatiakan yaitu pemahaman masyarakat terhadap segala bentuk program pemberdayaan masyarakat, sehingganya jika masyarakat masyarakat memahami lebih dalam apa itu pemberdayaan masyarakat akan lebih meningkatkan partisipasi masyarakat.

Dalam peran pemerintah desa dalam memberdayakan masyarakat didesa Bube ini jika dilihat pemerintah desa telah berupaya dengan baik terutama dalam mengontrol dan memastikan bahwa pemberdayaan ini nantinya dapat berguna pada setiap masyarakat, hanya saja kerjasama yang baik antara pemerintah desa dan masyarakat saja yang perlu untuk di tingkatkan , karena menginggat kurangnya partisipasi aktif dari pemerintah desa dan masyarakat membuat kerjasama yang baik antara pemerintah desa dan masyarakat masih sangat kurang sehingganya inilah yang menjadi hal yang perlu diperhatikan baik dari pemerintah desa dan masyarakat demi sukses dan berjalannya pemberdayaan masyarakat yang ada di Desa Bube.

\section{DAFTAR PUSTAKA}

Badan Pengawasan Keuangan dan Pembangunan . 2015 . dalam buku: Petunjuk Pelaksanaan Bimbingan dan Konsultasi Pengelolaan Keuangan Desa . 2015

Bahri. 2016. Pemberdayaan Masyarakat: Konsep dan Aplikasi, 2013, hal. 30-33); (Ariani, 2016, hal. 279-280

Durianto, Robert . 2013, hal. 24) Subejo dan Narimo dalam Mardikanto dan Soebiato (2012, h.31)

Nations, United . 2006. 956, h.83-92 dalam Tampubolon, 2006 Jurnal Administrasi Publik (JAP) VOL 1. 